Educational Philosophy and Theory, Vol. 32, No. 3, 2000

\title{
SYMPOSIUM
}

\section{Beyond the Habitual Paths of Reasoning}

\author{
PÁDRAIG HogaN
}

National University of Ireland Maynooth, Ireland

The phrase in the title comes from a passage on page 150 of Thinking Again. Employed by the authors in the course of an engagement with works of Kierkegaard and Derrida, it is also an apt phrase to give a suggestive summary of one of the chief themes in the book as a whole. The theme I have in mind here is really a twofold one: firstly, the book's critique-largely an unsympathetic one-of those paths of reasoning associated with the modernist legacies of the Enlightenment and their educational embodiments; secondly its critique-a more sympathetic one-of postmodern moves to abandon the grand ideals and universalistic pretensions of the Enlightenment's legacies. In this short contribution to the symposium I will concentrate on these two critiques.

To begin with the first critique, the authors point out that the Enlightenment's most notable legacy to education is the displacement of one kind of search for foundations and its replacement with another kind. What gets unseated is a Platonist conception which views knowledge as that which had its foundations in a changeless metaphysical world of ideas ['a transmundane realm of Forms' (p. 23)]. What the rationalist tenor of Enlightenment thinking installs instead is a modernist conception which views knowledge as that which has its foundations in reason as something universal. This modernist orientation becomes articulated in philosophy as the reflective consciousness 'critically examining its own limits and its own potential' (p. 27). Pointing to the anti-traditionalist thrust of this shift, and more particularly to its educational implications, the authors write:

Thus the conscious individual was the sovereign subject of knowledge. The strategic, 'political' value of this epistemic autonomy is in its legitimation of resistance to the 'corrupting' influence of 'mere opinion'-the mere opinion of others which should not easily outweigh the evidence of one's own experience or most rigorous and principled reflections. (p. 23)

The authors also identify 'the classic analytic philosophy of education elaborated by Peters and Hirst squarely within the modernist concern with secure foundations and the autonomy of reason. The following brief extracts from page 28 of Thinking Again illustrate this identification and trace its influence in three main emphases of that analytic philosophy: 
Hirst's Forms of Knowledge thesis clearly shares the same concern with the autonomy of differing kinds of intellectual pursuit ...

Peters' Transcendental Argument may be seen as a modernist attempt to entrench educational theory as a partially autonomous discipline by establishing the limits of value scepticism in the intellectual field.

[T] he moral views of Hirst, Peters and their colleague Robert Dearden, which informed their views of both the educational process in general and moral education in particular, were grounded in an unambiguously modernist view of the autonomy of ethics.

The significance of their first critique now becomes apparent in the authors' decisive rejection of the modernist tradition whose chief characteristics they have been sketching. The heart of this rejection lies in the claim that the search for foundations is a futile one; that epistemology cannot claim any special or disinterested status above the politics of competing perspectives. Thus a politics of knowledge becomes an inescapable fact of life for all 'pustfoundational philosophy'. The authors are acutely aware of the charge of relativism, or of 'radical abrogation of intellectual responsibility', which is made by traditionalist and modernist philosophers against any philosophy which rejects 'the very notion of foundations of knowledge and with it that of the individual as the sovereign subject of knowledge' (p. 24).

The authors point out that despite allegations of subversion made by conservatives, it is the principled pursuit of the modernist project itself-the commitment to critique and the evaluation of claims to validity - that eventually discloses the elusiveness of foundations (p. 26). They also show moreover that most of the major currents of philosophical thought that developed during the twentieth century have given up the search for secure foundations, and must therefore be regarded as postfoundationalist. They include in this regard the later philosophy of Wittgenstein; the post-analytic philosophy of science pursued by Lakatos, Kuhn and Feyerabend; much of the American pragmatist tradition from Dewey to Richard Rorty; the different strands of German philosophy associated with Heidegger, Gadamer, Habermas; and not least, in France, the poststructuralism of Foucault, the donconstructionism of Derrida and the postmodern philosophy of Lyotard. The authors acknowledge, however, that for philosophy to repudiate the notion of foundations 'raises problems as to the legitimacy of all and any knowledge claims: problems which in turn prompt questions about the authority and autonomy of educational institutions in general' (p. 24).

The form of postfoundationalist philosophy which becomes the main subject of the second critique, pursued most notably in Chapter 5, is postmodernist philosophy. Although the authors acknowledge early in the book (p. 5) that the philosophers they consider as postmodernists-Derrida, Foucault, Lyotard, Levinas-have mostly repudiated the description 'postmodernist', they argue that such philosophers can still be viewed as postmodernist thinkers in the sense that 'they help us think about the postmodern condition in which we find ourselves'. The most notable common characteristic evident in the works of these four thinkers, according to the 
authors of Thinking Again, is their contribution-in different ways-to a shift in the concept of ethics. In the case of Foucault the shift is evident in the 'outlining [of] an ethos without a normative core'; in the case of Lyotard it becomes 'a fractured vision of the social world as composed of a number of incommensurables'. The influence of Nietzsche strongly underlies both of these stances. With Derrida and Levinas, something more recondite is at play: in the case of Derrida, 'a vision of the subject as more vigilant and responsive to the Other'; in the case of Levinas, 'a conception of the Other as an anchorage for the command' (of God) (p. 59).

The second critique moves to the heart of its work with a summary exposition of some key themes in the philosophy of each of these four, followed by a critical review of the practical problems these philosophies still leave in the educators path. For instance, Foucault's critique of power/knowledge is incisive and illuminating insofar as it goes, but it is a critique undertaken for the sake of what? There are some suggestive indications of this 'what' in Foucault's last interviews (1984), but as far as explicit and positive practices are concerned, the authors correctly conclude that 'Foucault seems unwilling to recommend any alternative'. By contrast, the authors point out that the positive ethical demands at the heart of Levinas' philosophy are of their nature so demanding that only saintly individuals may be able to live up to them. Lyotard is criticised by the authors for giving too much weight to the 'incommensurablility' of different discourses, and thus for casting a disapproving eye from the start on the possibility of accommodations between many discourses (standpoints, traditions) which might be more inclusionary than exclusionary in character. For Lyotard, it would seem that all such accommodations are acts of violence (p. 70).

Lyotard's paths of reasoning play a stronger part in the book's second critique, however, than do those of any of the other three. His explorations of 'performativity' and of its dominance in postmodern societies are a major inspiration of the authors' criticisms of education reform policies of most countries in the English-speaking world in recent decades. Lyotard's theses also feature prominently in the authors' largely sympathetic critique of postmodernism. In this latter respect some of these theses escape a bit too lightly in my view. Let me explain this. Lyotard describes 'the postmodern' as an attitude of 'incredulity to metanarratives'. When they speak unquestioningly of the 'collapse of grand narrative' (p. 102) the authors seem to me to acquiesce too readily in one of Lyotard's more questionable conclusions. They seem to accept as an accomplished fact Lyotard's indiscriminate rejection of 'the dialectics of spirit, the hermeneutics of meaning, the emancipation of the working subject'. On my own view, there is something breathtakingly audacious in the scale of Lyotard's dismissal here. If the target of the dismissal were primarily the teleological or historicist emphasis in the works of Hegel or Marx, it would be difficult to deny that Lyotard's appraisal was broadly accurate as a conclusion about the philosophical temperaments of contemporary Western cultures.

But Lyotard seems to be going much further than ridding Hegel and Marx of teleological content. More subtly, he seems to be consigning the entire works of Hegel and Marx to the ranks of what must be considered passé in a postmodern age, and doing the same to most of the inheritances of Western philosophy. In other 
words I am arguing that the sweeping force of Lyotard's work harbours a tendentious purpose; one which I would be keen to see the authors investigate. Though ostensibly an investigation of the state of knowledge in advanced technological societies, The Postmodern Condition is as much a polemic against philosophers in the Enlightenment tradition as it is a 'report on knowledge'. Its analysis receives an unwarranted force and impetus from Lyotard's inhospitality to some of the more central figures in the traditions springing from the Enlightenment, including not only such early champions of modernity as Humboldt and Schleiermacher, but also later ones like Habermas.

Where the philosophy of education is concerned, the consequences of such a stance for constructive action would seem to be debilitating ones. It is difficult to see in education after postmodernism-à la Lyotard-anything which would equal in importance the Nietzschean-inspired task of a sustained confrontation with inheritances of learning. These inheritances would now be chiefly significant as examples of a knowledge pervaded by hegemonic preconceptions. Unlike the shift from Nietzsche evident in Foucault's final works and interviews, or the 'messianic' motifs in the later works of Derrida, Lyotard's answer to the practical question 'critique for the sake of what?' seems confined to renewing the search for dissent, i.e. 'paralogy', or to bearing witness to 'differends' within and between different 'language games'. The authors of Thinking Again criticise Lyotard's exclusive embrace of paralogy as a way of resisting performativity. They perceptively point out that whatever about the merits of 'paralogy' in the conduct of a language game such as science, Lyotard neglects to recognise Wittgenstein's distinction between the concept of 'language games' on the one hand and the more inclusive concept of 'forms of life' on the other (e.g. public education), within which language games of many kinds are themselves experienced.

I would be keen to see the authors explore this line of argument further, with a view to sketching some outlines-albeit provisional ones-for defensible educational practice. By 'outlines' then, I mean something more concrete than what is contained in the 'Prospect' at the end, but I do not mean something that is universal in any a priori sense. Rather I mean candidates for engaging the productive thoughts and actions of teachers; candidates that aspire to be universally worthy of the commitments of teachers. I believe my own keenness here would be shared by hard-pressed teachers in many post-reform circumstances who are struggling, less to construct their selves than to redefine those solidarities of teaching and learning that constitute the integrity of their work. Let me conclude by suggesting that the paths of reasoning that will advance the practical heart of this work are likely to find their best inspirations elsewhere than in the more individualist of Nietzsche's legacies. 